\title{
Acknowledging Learner Multiple Identities in the EFL Classroom
}

\author{
Nugrahenny T. Zacharias \\ English Department, Faculty of Language and Literature, \\ Satya Wacana Christian University, \\ Diponegoro 52-60, Salatiga, Central Java, Indonesia \\ e-mail: Ntz.iup@gmail.com
}

\begin{abstract}
Students in any educational settings represent a wide array of social and cultural identities: as men/women, as foreigners or locals, as native speakers or non-native speakers, as individuals with particular beliefs, as members of families, organization, ethnic groups or society at large. Despite their multiple identities, English language pedagogy continues to subsume these diverse identities into a single linguistic basket labeled non-native speakers. Although the label has now been widely challenged (see, among others, Jenkins, 1996; Phillipson, 1992; Seidlhofer, 1999; \& Shuck, 2006), the label persists because suggestions have not been accompanied by microlevel classroom techniques on how to address students' various identities in the classroom. This paper seeks to address this gap by recommending practical classroom techniques to accommodate learners' multiple identities.
\end{abstract}

Key words: identities, imagined communities, bilinguals, multicompetence, community of practice

There is a prevailing myth in the EFL pedagogy that to succeed academically, English as a Foreign Language (EFL) students need to minimize, if not getting rid of, their ethnic (L1) identities and adapt to native-speaker norms and standards. I still remember the time when my teacher asked me to pick an English name in the classroom to replace my Indonesian name. Later, I learned that she was inspired by a teaching method called Suggestopedia. The underlying idea of the method was to make students feel less inhibited since their performance was that of the other person. However, the method overlooks the idea that learners' L1 culture is an integral part of their identities and cannot simply be "replaced". My personal experience illustrates the realization that learning a foreign language is more than acquiring a set of grammatical, lexical, and 
phonological forms of the language. More importantly, it is a "reconstruction of selves" (Pavlenko \& Lantolf, 2000).

Realizing the importance of learners' multiple identities, little is actually done in the classroom to make learners aware of the identity repertoires available to them when speaking English. If English, a lingua franca of the world, belongs to the people who speak it (Jenkins, 2007; Norton, 1997), and not only to the so-called native speakers, then questions need to be asked as to what extent classroom methodologies and techniques accommodate EFL learners' dynamic and multidimensional identities.

It is important for teacher to acknowledge the identities that learners bring into the classroom. A study conducted by Shardkova and Pavlenko (2004) demonstrates that English learners experience significant identity conflicts when speaking English. Similarly, studies conducted by BashirAli (2006) and Norton (1997) illustrate that some English learners felt the need to deny their L1 cultures to assimilate into the mainstream English academic discourse. Since in EFL contexts, the space to use English actively is somewhat limited, the classroom becomes an important place to "validate learners as interlocutors in the new speech community" (Boxer \& Cortes-Conde, 2000, p. 203).

Knowing the significant contribution of EFL classroom to language learning, this paper attempts to suggest teaching strategies that can accommodate EFL learner multiple identities. As pointed out by Boxer and Cortes-Conde (2000), the accommodation of learner identities in the classroom has important consequences for English learners' language competence. Prior to discussing my suggestion, it is necessary to understand the meaning of the term 'identities' along with factors contributing to their construction. Thus, I will begin by exploring the different ways the term identities have been coined in the field of Second Language Acquisition (hereafter, SLA).

\section{EXPLORING THE NOTIONS OF L2 IDENTITIES}

The process of trying to pin down the term identity is extremely complex. Many people have attempted to define the term identities. Although there are a number of similarities among researches across disciplines, there is a lack of conformity of what it means by identities. The meaning of the term identities has evolved from seeing them as 
synonymous to a "stable core self" (Hall, 1996) to dynamic, contradictory, and multiple dimensions of a person (see Block, 2006, 2007; Pavlenko, 2002). Ha (2008) argues that there is different conceptions of identities between the West and the East. Western scholars tend to perceive identities as "hybrid and multiple" (p. 64), whereas Eastern scholars see identities as related to a sense of belonging. Despite the different ways of viewing identity, recently English learner identities have been addressed and studied from a poststructuralism point of views which conceptualize identities as multiple, diverse, dynamic, and contradictory.

Several studies have illustrated the multidimensional and non-unitary natures of learner identities (e.g. Bosher, 1997; Lam, 2000; Norton, 2000; Armour, 2004). One of the most cited studies is Norton (2000). One of her participants, "Martina", has multiple identities: as an immigrant, a mother, a language learner, a worker and a wife. As an immigrant and a language learner, she never felt comfortable speaking English. However, her identity as a mother allowed her to engage in a long conversation with her landlord when he accused her of breaking a lease agreement.

Several people (see Pierce, 1995; McKay \& Wong, 1996; Armour, 2004) indicate that negotiating multiple identities is a site or struggle. "Michael Lee”, a participant in McKay and Wong's (1996) study, shows an active attempt to resist the way he was positioned as an ESL student. At the first language assessment, he decided not to write on the suggested topic of family or school. Instead, he chose to write about his hobbies (sports and pets). McKay and Wong concluded that Michael Lee's attempt to "write about his hobbies" illustrated delicate social negotiations to fashion desirable identities. He resisted to be passive recipients of positioning and attempted to reposition and deploy discourses and counter discourses.

Another study illustrating the complexities of EFL identities can be seen from Ali's (2006) study. The study shed slightly different insights on L2 identities. Instead of maintaining her L1 identities, "Maria" went to a great length concealing her ethnic identity to be part of the collective social identity in the school. She did so by adopting the common linguistic and social traits shared by the dominant African-American social group in the school contexts. Her eagerness to gain entry into the dominant group led her to resist learning Standard American English (SAE) despite its usefulness for her future academic success. She also refused to be labeled an ESL student because ESL students were at the bottom of the school's 
social hierarchy and were considered inferior by most students. Her priority was not to be academically successful but to be socially accepted and included within the social sphere that dominated the school.

Others, such as Kramsch (1993), Norton (2000) and Su-Kim (2003), see bilingual identities as dynamic and changing over time. Kramsch (1993) asserts that sociocultural identities are not static, deterministic constructs that EFL students bring to the classroom and then take away unchanged at the end of a lesson or course. Wenger (1998) argues that identity should be seen as an ongoing process of negotiating the self. A similar idea can be drawn from Ueno's study (2001). He studied 11 bilingual Japanese middle school students who attended a Japanese Saturday school in a large mid-western city. The findings showed that none of the students interviewed could give a clear-cut definition of their identities. While they appreciated both sets of values, American and Japanese, they never tried to choose one or the other exclusively. In fact, half of the participants claimed that they would locate their identities midway between American and Japanese. Interestingly, they did not find this fact depressing.

In an interesting way, Ueno's (2001) study contradicts studies suggesting the negotiation of EFL identities as a site of struggle. In fact, the participants in Ueno's study enjoy belonging to both of them as well as, in a sense, to neither of them. Even though the participants accept American values of heterogeneity and individualism, they did not neglect their Japanese values (homogeneity and collectivism). Ueno's study highlights that identity formation is fluid and complex rather than clear-cut and solid.

To sum up, studies on identities show that L2 identities are multidimensional, a site of struggle, fluid, and changing over time. The discussion also highlights that learning a second language does not necessarily mean abandoning learner ethnic identities. In fact, several studies indicate that successful second language learners are the ones who are able to maintain their ethnic identity as they adapt to L2 culture.

\section{FACTORS AFFECTING L2 IDENTITY CONSTRUCTION IN THE CLASSROOM}

Identities do not exist in a vacuum. While research has indicated that in real life English learner identity construction is a complex interplay of many variables, in the classroom I found there are two prominent factors 
affecting learner identity construction. Those factors are teaching approaches and textbooks, which will be discussed thoroughly in the following paragraphs.

\section{Teaching Approaches}

Pierce (1995) points out the need for teachers to accommodate English learner dynamic identities in the classroom. She draws an example from "Mai", one of the participants in her study. Mai was a young woman from Vietnam who after completing a 6-month ESL course continued to take ESL courses at night to improve her spoken and written English. Mai had to make a great sacrifice to attend this course. She needed to juggle the course between her already hectic life of working and taking care of her family. Given the sacrifices she made to attend the course, she expressed a great concern of one course in particular that led her to drop the course. She was frustrated sitting for a whole lesson only to listen to one student talk about his country. Norton (1997) argued that while Mai's teacher might incorporate the lived histories of the students in her teaching approaches, the present approach did not accommodate Mai's needs to learn English in the new country.

One might ask what should the teacher do differently to accommodate English learners such as Mai? Norton (1997) explained that the lack of involvement felt by Mai might be due to the teacher's failure to acknowledge the learners' identities as immigrants in the new country and thus, their language needs. One way to address the discrepancy between Mai's dissatisfaction and the teacher's teaching approach is to encourage learners to critically compare the learners' English needs in their native countries with the more recent experiences in the new country. The lack of attention given to Mai's immigrant identities results in Mai's little involvement in the classroom. Reflecting on Mai story, it can be learn that the issue of identity is not only abstract and theoretical but also has a direct bearing on language learning and teaching.

\section{Textbooks}

Other than teaching approaches, language textbooks play a unique role in empowering (or disempowering) EFL learner identities. Shardakova and Pavlenko (2004) conducted a study on classroom textbooks to explore the 
identity options accommodated in these textbooks. They found that the textbooks in question provided limited identity options for learners. The ideal and imaginary English learner identities promoted by the textbooks was heterosexual White middle-class and "problem-free" males. By making White and heterosexual men as a model of English speakers, Shardakova and Pavlenko claim that the authors of these texts neglect ways in which English learners vary in terms of gender, race, ethnicity, sexual orientations, religious beliefs, and a plethora of other factors. Therefore, they encourage classroom teachers to recognize the diversity of language learners who may at times, and most often, different from those of "model learners" promoted in textbooks. Shardakova and Pavlenko (2004) further add that the portrayal of English communities as glamorous and problemfree in the textbooks studied may deprive students of linguistic resources they need to position themselves in difficult interactions, such as when negotiating their gender, sexual, racial or cultural identities. The "oversimplified" and stereotypical interactions illustrated in textbooks may influence and at times even shape, the students' motivation, degree of engagement with the target language and culture, and the development of their intercultural competence.

Canagarajah's (1993) study on US-published ESL textbooks used in a Sri Lankan classroom also underlines the importance of textbooks to language learner identity construction. His study reveals that the dialogs and narratives in the textbooks portray racial and gender bias, as well as, Western middle-class values like consumerism, thrift, delayed gratification, and social mobility. In reaction to the textbooks, the data show that rural Tamil students adopted a range of discursive strategies to deal with ideological conflicts posed to them by the textbooks. Students' reactions include direct hostility, parody, exaggeration, or mockery. Based on the findings, Canagarajah (1993) recommends textbooks authors to engage discourses that are relevant to the students' lives.

Kinginger's (2004) study on French textbooks shows that the implied audience of these textbooks were members of the middle-class who live in "mansions," "apartments," or "pavilions" and have the means "to envisage France in the modern-day version of the Grand Tour, ordering wine at refined cafes, buying silk scarves from obsequious salespeople, contemplating celebrated worked of arts” (p. 225). Kinginger (2004) found that these texts alienated working-class students in her university French class. 


\section{ACKNOWLEDGING EFL LEARNERS' IDENTITY IN THE CLASSROOM: SOME ISSUES AND CONCERNS}

It is well accepted in SLA that language use is pivotal for language learning to be successful. While in English as a second language (ESL) settings such as Singapore, Malaysia, and the Philippines, ESL learners may have the opportunity to use English outside the classroom, in EFL settings the opportunities to use English outside the classroom is relatively limited. In Indonesia, attempts of using English outside the classroom may come across as snobbish or overconfident as stated by some of my students. Similar to the participants in Su-Kim's study (2003), in Indonesia using English can be interpreted as being westernized and being less Indonesian. This is perhaps the reason why my students did not respond to my advice to use English outside the classroom with glee. For these reasons, the role of the classroom in EFL contexts as primary exposure of English becomes even more crucial.

As a major source of input for English learning, the classroom provides settings where EFL students construct their bilingual identities. Since language and identity are interrelated, teachers need to make learners aware of the need to shuttle between different identities so that their use of English will not distant, offend, and annoy the member of the local group. Thus, EFL educators need to critically examine aspects affecting student identity construction. I acknowledge that classroom pedagogy cannot predict accurately the kinds of identity construction learners will be engaged in target language communities nor can it accommodate and replicate all communities of practice learners will encounter outside the classroom. What teacher educators can do is to help English learners to be aware of their multiple identities. One way to do this is by raising awareness of the identity options available when learners are using English. To this end, I would like to recommend several things that EFL pedagogy can do.

\section{Teacher Educators' Awareness of the Issues Surrounding Bilingual Identities}

For any educational changes to take firm footings, I personally believe teachers themselves need to be aware of the identity issues of bilinguals. This is particularly because EFL teachers are the mediator between the 
classroom community and the communities of practice whose language students learn. Hall (1995) asserts that teachers are influential in learners' identity construction. Teachers can either create or impose identities on learners. Several studies (see, among others, Norton, 2000; Bashir-Ali, 2006) indicate that generally there is a lack of understanding of identity issues in bilingual students.

In my opinion, one way to raise teachers' awareness is by integrating issues of bilingual identities and/or language minority students in courses or formal discussion/seminars offered in EFL pre-service and in-service teacher educational programs. As EFL teacher educators are themselves bilinguals, such discussions will not only benefit the students but also the teachers themselves as they construct their professional teacher identity. The need to reinforce teacher identity is best illustrated by Pavlenko's (2003) study. Some in-service teacher participants in her study stated that even though they have already been teaching English in their home country, moving to the US forced them to "change" their identities from teachers to students. The shift of status from English teachers to English learners led them to feel less competent and adequate than they thought they were. The fact that some teacher educators program continue to promote native-speaker competence has positioned these in-service students as passive, incompetent, stupid, and childlike. The frustration that the participants felt, Pavlenko (2003) speculates, is because these students are not made aware of other identity alternatives other than the native/nonnative speakers. Thus, the participants did not have any other positive identity options to fall back on when they could not join the nativesspeaker community.

To make students' aware of their multiple identities, Pavlenko (2003) recommends classroom pedagogy to expose students to readings and discussion aimed to solidify students' knowledge base about the natures of bilingual users. By doing so, students can feel legitimate, instead of deviant, L2 users.

\section{Forming Community of Practice of Multicompetence Language Users in the EFL Classroom}

Other than the NS/NNS dichotomy, what other identity options can teachers make students aware of? Instead of encouraging students to model their competence after native-speaker models, Pavlenko (2003) 
recommends teachers to develop classroom discussion and reflections encouraging students to become part of a community of multicompetence English speakers. Cook's (1992, 1999) notion of multicompetence suggests that people who know more than one language have a distinct state of mind than those of monolinguals. She asserts that the mind of bilinguals is not equal to two monolinguals and that these bilingual English users should be considered legitimate L2 users.

Several people (see, among others, Pavlenko, 2003; Pavlenko, 2000; Waas, 1997) suggests that through discussions of multicompetence, bilingualism, and the effect of second language acquistion (SLA) to the first language, students can see their own competence differently and more positively. In particular, Pavlenko (2003) offers several benefits of introducing multicompetence in pedagogy (pp. 262-263):

- It offers an appealing alternative for students who are eager to reframe their own competence;

- It allows bilingual students to reimagine themselves in a new and much more positive light and to position themselves differently with regard to their multilingualism;

- As a concept, mutlicompetence has a therapeutic effect; it affects not only students' views of their linguistic competence but also their selfesteem as legitimate users of English.

Realizing the notion of multicompetence has helped me to see myself in a more positive light. Prior to knowing the concept of multicompetence, I always felt inferior and nervous whenever I spoke to native speakers of English despite fifteen years of learning English and more than 7 years of using English actively in my professional life as an EFL teacher. I have this belief that I needed to be perfect. Of course, this false belief was detrimental to my self-esteem as an English user. I often made silly mistakes, stuttered, and forgot words. The notion of English users as multicompetence language user highlight what bilingual English users can do rather than what they cannot do as the term "nonnative speaker" does.

\section{Developing Pragmatics Awareness and Competence}

Several authors suggest that most learners experience identity conflicts due to their linguistic inadequacy. Alim's (2005) and Ogbu and Simons's (1994) studies illustrate that ESL learners were often placed into a 
subordinate status because they are perceived as racially and culturally different and they do not know the linguistic tools (e.g. particular choice of words, phrases, and phonological forms) to gain entry into the dominant speech communities. Kubota (2001) stated that these learners often become victims of ridicule because of their accents, their low level English proficiency, and their appearance. While these conflicts might not have direct detrimental effects on learners' linguistic competence, Pavlekno (2000) suggests that they may limit learners' access to interactional opportunities in the target speech communities and affect their overall communicative competence.

While learning a language in its natural context is essential for language learning, gaining access into these communities of practice is not without problems. Norton's study (2000) shows that natural language learning does not necessarily provide language learners the opportunities to practice the target language in a supportive environment regardless the fact that learners are surrounded by fluent speakers of the target language. Her study indicates that natural language learning is marked by unequal power relations in which language learners struggle for access into the dominant English speakers.

What classroom teachers can do is helping learners to develop "the right to speak” (e.g. Pierce, 1995; Norton, 2000). Certainly, language plays a prominent role to develop learners' right to speak as language affects one's identity and vice versa (Ochs, 1993; Pao, Wong, \& Tueben-Rowe, 1997). Ochs (1993) notes that it is through language that a person negotiates a sense of self within and across different communities of practice at different points in time, and it is through language that a person gains (or denied) access to powerful social networks giving learners the opportunity to speak. This entails pragmatic awareness of knowing when to talk, what others want to talk about, and how to gain entry and access into conversations.

\section{Critically Examine the Imagined Communities Portray in Texts}

Wenger (1998) points out that learners develop their identities not only by engaging in a community of practice, but also through imagining their position within it. Thus, imagination plays a great role in developing learner multiple identities. One aspect in the classroom contributes to creating imagined communities, as noted earlier, is pedagogical texts. By 
pedagogical texts, I mean any materials such as textbooks, teaching aids, and supplementary materials that create and shape language learners' imagined communities. Kanno and Norton (2003) define imagined communities as "... groups of people, not immediately tangible and accessible, with whom we connect through the power of the imagination" (p.241). Shardakova and Pavlenko (2004) assert that texts possess a unique authority to construct and mediate alternative cultural and linguistic identities. Misrepresentation, stereotyping, and oversimplification of these imaginary worlds could lead to cross-cultural miscommunication, frustration, offence, and conflict. In addition, learners show resistance in cases where their own linguistic and cultural values come into conflict with those imposed on them by the texts.

What kinds of text are suitable to accommodate English language learner identities? Pierce (1995) recommends teachers to incorporate personal narratives illustrating the lived experience and social identities of bilinguals. One example is a poem by Kenneth Wee's Festival (see Appendix A for the complete poem). The character "I" experience identity conflicts. Although he identifies himself as a Chinese, he cannot speak Chinese. He appears to disfavor some parts of Chinese culture like the dishes and the dances. However, the poem ends with thought-provoking line I'm proud to be Chinese in English which can serve as a spring-board to address the fluidity and complexity of bilingual identities. The followings are some other discussion questions to address learner multiple identities:

- What does 'I'm proud to be Chinese' in English mean?

- Look at the author's name (Kenneth Wee), what does it suggest about his identity?

- What are some benefits of being able to speak English? How do these benefits change overtime?

- Do you feel learning English has affected your ethnic identities? In what way?

Surely, the answers to these questions are not as important as the process through which these questions will guide students through the process of understanding issues underlying identities. Students can be made aware of the natures of bilingual identities as a site of struggle, complex, and changing over time. The discussion also allows students to evaluate and reflect on their bilingual identity constructions. For the discussion to be 
worthwhile, teachers need to create a safe atmosphere for students to express stereotypes, concerns, dilemmas, conflicts, and other pragmatic exploration.

If teachers do not have the liberty to choose their own texts, then, existing texts can be used although care needs to be taken in approaching the texts. Boxer and Cortes-Conde (2000) maintain that the formation of bilingual identities involve not only incorporating L2 pragmatics but also making learners aware of their L1 pragmatics. This can be done by drawing contrast between L1 and L2 pragmatics. A study conducted by Boxer and Cortes-Conde (2000) show that students were more enthusiastic when their L1 cultures were addressed and accommodated in the classroom.

\section{CONCLUSION}

This article attempts to highlight that learning English is more than acquiring linguistic aspects of the language. Rather, it is a complex social practice involving a transformation of learners' multiple identities. Despite the close relationship between language learning and learners' identities as previously discussed, little is actually done in the classroom to address learners' identities when learning English. In this article, I am not intending to offer a magic formula that can empower learners' identities overnight. Rather, this article is a modest attempt to invite teachers to pay attention to their learner identities when designing courses, preparing materials as well as selecting teaching approaches. I acknowledge that there are no simple linguistic or pedagogical formulae to direct how to compose feasible identities for certain communities of practice as pointed out by Ochs (1993). However, I do believe that there are pedagogical approaches and attitudes that teacher can take as this paper aims to illustrate.

\section{REFERENCES}

Alim, H. S. (2005). Critical language awareness in the United States: Revisiting issues and revising pedagogies in resegregated society. Educational Researcher, 34, 21-31.

Armour, W. S. (2004). Becoming a Japanese language learner, user, and teacher: Revelations from life history research. Journal of Language, Identity, and Education, 3, 101-125. 
Bashir-Ali, K. (2006). Language learning and the definition of one's social, cultural, and racial identity. TESOL Quarterly, 40, 628-639.

Block, D. (2006). Identity in applied linguistics. In T. Omoniyi, \& G. White (Eds.), The sociolinguistics of identity (pp. 34-49). London: Continuum.

Block, D. (2007). Second language identities. London: Continuum.

Bosher, S. (1997). Language and cultural identity: A study of Hmong students at the postsecondary level. TESOL Quarterly, 31, 593-603.

Boxer, D., \& Cortes-Conde, F. (2000). Identity and ideology: Culture and pragmatics in content-based ESL. In J. K. Hall, \& L. S. Verplaestse (Eds.), Second and foreign language learning through classroom interaction (pp. 203-219). Mahwah: Lawrence Erlbaum Associates.

Canagarajah, S. (1993). American textbooks and Tamil students: Discerning ideological tensions in the ESL classrooms. Journal of Language, Culture, and Curriculum, 6, 143-156.

Cook, V. (1992). Evidence for multicompetence. Language Learning, 42, 557-591.

Cook, V. (1999). Going beyond the native speaker in language teaching. TESOL Quaterly, 33, 185-209.

Ha, P. L. (2008). Teaching English as an international language: Identity, resistance, negotiation. Clevedon: England Multilingual Matters.

Hall, J. K. (1995). (Re)creating our worlds with words: A sociohistorical perspective of face-to-face interaction. Applied Linguistics, 16, 206-232.

Hall, S. (1996). Introduction: Who needs 'identity'? In S. Hall, \& P. D. Gay (Eds.), Questions of cultural identity (pp. 1-17). London: Sage Publication.

Kanno, Y., \& Norton, B. (2003). Imagined communities and educational possibilities: Introduction. Journal of Language, Identity, and Education, 2, 241-249.

Kinginger, C. (2004). Alice doesn’t live here anymore: Foreign language learning and identity construction. In A. Pavlenko, \& A. Blakcledge (Eds.), Negotiation of identities in multilingual contexts (pp. 219-242). Clevedon: Multilingual Matters.

Kramsch, C. (1993). Context and culture in language teaching. Oxford: Oxford University Press. 
Kubota, R. (2001). Discursive construction of the images of U.S. classroom. TESOL Quarterly, 35, 9-38.

Jenkins, J. (1996). Native speaker, non-native speaker and English as a foreign language: Time for change. IATEFL Newsletter, 131, 10-11.

Jenkins, J. (2007). English as a lingua franca: Attitude and identity. New York: Oxford University Press.

Lam, W. S. E. (2000). L2 literacy and the design of the self: A case study of a teenager writing on the internet. TESOL Quarterly, 34, 457-482.

McKay, S. L., \& Wong, S. C. (1996). Multiple discourses, multiple identities: Investment and agency in second-language learning among Chinese adolescent immigrant students. Harvard Educational Review, 66, 577-608.

Norton, B. (1997). Language, identity, and the ownership of English. TESOL Quarterly, 31, 409-429.

Norton, B. (2000). Identity and language learning: Gender, ethnicity, and educational change. Harlow: Pearson Education.

Ochs, E. (1993). Constructing social identity: A language socialization perspective. Research on Language and Social Interaction, 26, 287-306.

Ogbu, J. U., \& Simons, H. D. (1994). Final report: Cultural models of achievement: A quantitative test of Ogbu's theory. [ERIC Document Reproduction Service No. ED 376 515].

Pao, D. L., Wong, S. D., \& Tueben-Rowe, S. (1997). Identity formation for mixedheritage adults and implications for educators. TESOL Quarterly, 31, 622631.

Pavlenko, A., \& Lantolf, J. (2000). Second language learning as participation and reconstruction of selves. In A. Pavlenko, \& J. Lantolf (Eds.), Sociocultural theory and second language learning (pp. 155-178). Oxford: Oxford University Press.

Pavlenko, A. (2000). L2 influence on L1 in late bilingualism. Issues in Applied Linguistics, 11, 175-205.

Pavlenko, A. (2002). Poststructuralist approach to the study of social factors in second language learning and use. In V. Cook (Ed.), Potraits of the L2 user (pp. 277-302). Clevedon, England: Multilingual Matters. 
Pavlenko, A. (2003). I never knew I was a bilingual: Reimagining teacher identities in TESOL. Journal of Language, Identity, and Education, 2, 251-268.

Peirce, B. N. (1995). Social identity, investment, and language learning. TESOL Quarterly, 29, 9-31.

Phillipson, R. (1992). Linguistics imperialism. Oxford: Oxford University Press.

Seidlhofer, B. (1999). Double standards: Teacher education in the expanding circle. World Englishes, 18, 233-244.

Shardakova, M., \& Pavlenko, A. (2004). Identity options in Russian textbooks. Journal of Language, Identity and Education, 3, 25-46.

Shuck, G. (2006). Racializing the nonnative English speaker. Journal of Language, Identity, and Education, 5, 259-276.

Su-Kim, L. (2003). Multiple identities in a multicultural world: A Malaysian prespective. Journal of Language, Identity, and Education, 2, 137-158.

Ueno, J. (2001). Detraditionalisation: Japanese students in the USA. Language, Culture, and Curriculum, 14, 76-89.

Waas, M. (1997). First language loss: Reflex, responses, repartee and sound symbolism. Language Problems and Language Planning, 21, 119-133.

Wenger, E. (1998) Communities of practice: Learning, meaning and identity. New York: Cambridge University Press. 


\section{APPENDIX}

\section{Festival}

We sit in a corner, my friends and I

In a house filled with the roaring of the

Docks and harbours of our ancestors, and the

Colours of the sun which burned their fields.

The old men talk at the tables,

Remembering old times. We know them

[5]

Not, nor the language that they speak,

Yet we are relatives, only two generations apart.

We watch the television, glued to its screen,

Not knowing the meaning of the lotus seeds

We unseeingly eat.

They are just more candy to us.

When the dinner is brought on,

With special foods prepared by the elders,

We grimace at the 'tasteless' stuff

And think longingly of pizzas.

Somewhere down the street

Lion dancers twirl to heart thumping music.

In my room we, too, dance,

But to the latest rock hits.

On my door hang spring couplets;

Quotations from Shakespeare.

Door gods adorn our entrances

Posters of Schwarzenegger and Stallone.

We watch the festivities

And are reminded of our culture, our roots

And we think 'I'm proud to be Chinese'

In English.

Kenneth Wee 